\title{
Application of AQbD to cIEF of Protein Biopharmaceuticals
}

\author{
Ju Hyeon Lim* \\ New Drug Development Center, Osong medical innovation foundation, Republic of Korea
}

*Corresponding author: Jong Won Kim, New Drug Development Center, Osong medical innovation foundation, Republic of Korea

\begin{tabular}{|c|c|}
\hline ARTICLE INFO & ABSTRACT \\
\hline Received: 慧 November 01, 2019 & \multirow{4}{*}{$\begin{array}{l}\text { Recombinant monoclonal antibodies (mAbs) have become a wide range of relevant } \\
\text { for the treatment of various diseases. Because of their inherent complexity structure } \\
\text { and safety reasons, it needs to control all the processes for achieving a consistent } \\
\text { product that is absolutely necessary. In short communication shows that the importance } \\
\text { of analytical quality by design of biopharmaceutical agents and the current analytical } \\
\text { methods for mAbs will be discussed. } \\
\text { Abbreviations: MAbs: Monoclonal Antibodies; AQbD: Analytical Quality by Design; } \\
\text { MODR: Method Operable Design Regions; OOT: Out-of-Trend; OOS: Out-of-Specification; } \\
\text { PAT: Pharmaceutical Analytical Technology; HIC: Hydrophobic Interaction Chromatog- } \\
\text { raphy; CEX: Cation Exchange Chromatography; cIEF: Capillary Isoelectric Focusing; CZE: } \\
\text { Capillary Zone Electrophoresis }\end{array}$} \\
\hline Published: 㹃 November 08, 2019 & \\
\hline $\begin{array}{l}\text { Citation: Ju Hyeon Lim. Application of } \\
\text { AQbD to cIEF of Protein Biopharmaceuti- } \\
\text { cals. Biomed J Sci \& Tech Res 22(4)-2019. }\end{array}$ & \\
\hline BJSTR. MS.ID.003782. & \\
\hline
\end{tabular}

\section{Introduction}

Protein biopharmaceuticals like monoclonal antibodies (mAbs), recombinant and therapeutic proteins are recently in widespread treated of various diseases including cancer, autoimmune disease, cardiovascular, hematology and so on. In particular, mAbs are an emerging class of therapeutic agents recently being developed by many global pharmaceutical companies [1]. They have a marvelous therapeutic and commercial value which makes them the top 10 best sellers of pharmaceuticals for several past years. The complexity of therapeutic proteins is far exceeding that of other small molecule drugs. Therefore, they have to $150 \mathrm{KDa}$ molecular weight make the implementation of analytical quality by design $(A Q b D)$ as an essential strategy to assure the critical quality or optional analytical method during the drug development process. These AQbD helps in the development of a robust and cost-effective analytical method that is applicable throughout the lifecycle of the product, to facilitate the regulatory flexibility in the analytical method. It capable of the freedom to change method parameters within a method's design space, referred to as the method operable design regions (MODR) [2]. AQbD approach reduces the number of out-of-trend (OOT) results and out-of-specification (OOS) results due to the robustness of the methods within the region. It is a current trend among the pharmaceutical industry to implement analytical quality by design (AQbD) in the method development process as a part of risk management, pharmaceutical development, and pharmaceutical quality system (ICH Q10). Recently, many pharmaceutical industries have questions and require a lot of discussions on implementation $\mathrm{AQbD}$ and its correlation with other components of the pharmaceutical quality system. Also, its survey concludes that many researchers have adopted $\mathrm{QbD}$ principles to the development of analytical methods and they are termed analytical AQbD [2]. Thus, AQbD in the pharmaceutical quality system correlates with a product by design and pharmaceutical analytical technology (PAT).

\section{Method of cIEF Analysis}

The development of analytical platforms that characterize charge heterogeneity therapeutic proteins, such as monoclonal antibodies, should be confirmed using various and accurate analytical methods. Because of their complexity due to a large number of heterogeneities, there is a crucial need for analytical methods to provide a comprehensive in-depth characterization of these molecules [3]. Ultimately, these analytical platforms could provide accurate and reliable biopharmaceutical information. 
Therefore, analytical platforms must be developed to exactly of the physicochemical properties of biopharmaceuticals and define and monitor quality controls at all drug development stage.

In particular, various PAT in chromatographic and electrophoretic techniques such as exchange chromatography (CEX), hydrophobic interaction chromatography (HIC) and capillary Isoelectric Focusing (CIEF) and capillary zone electrophoresis (CZE) has increased significantly in past years, because it is important tools of analyzing charge heterogeneity [1]. Predominantly, charge variants analysis of monoclonal antibodies (mAbs) using cation exchange chromatography (CEX) is a major analysis of posttranslational modifications present on the target molecule. These methods using traditional salt or $\mathrm{pH}$-based eluents are not optional specific complex of therapeutic proteins due to nonvolatility or high ionic strength. Also, cation exchange chromatography always boasted that their instrumentation is fully automated whereas in electrophoresis all methodologies are mainly manual and labor-intensive (especially 2-D map analysis) [1,4]. Additionally, capillary zone electrophoresis (CZE) is a powerful separation tool of specific protein biopharmaceutical characterization analysis. These optimized methods facilitated the separation of charge variants including acidic and basic variants of the therapeutic proteins. Therefore, CZE separates protein moieties close to their native state and is specific physicochemical analytical analysis that can be used in parallel with other orthogonal methods for characterization and comparability [4-11].

\section{References}

1. Chen W, Jiang K, Mack A, Sachok B, Zhu X, et al. (2015) Synthesis and optimization of wide pore superficially porous particles by a one-step coating process for separation of proteins and monoclonal antibodies. Journal of Chromatography A 1414: 147-157.

ISSN: 2574-1241

DOI: $10.26717 /$ BJSTR.2019.22.003782

Ju Hyeon Lim. Biomed J Sci \& Tech Res

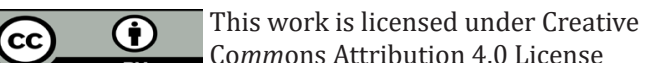

Submission Link: https://biomedres.us/submit-manuscript.php
2. Espinosa de la Garza CE, Perdomo Abundez, FC, Padilla Calderón J, Uribe Wiechers J, M Pérez NO et al. (2013) Analysis of recombinant monoclonal antibodies by capillary zone electrophoresis. Electrophoresis 34(8): 1133-1140.

3. Szabolcs Fekete, Davy Guillarme, Alain Beck (2015) Characterization of cation exchanger stationary phases applied for the separations of therapeutic monoclonal antibodies. Journal of Pharmaceutical and Biomedical Analysis 111: 169-176.

4. Szabolcs Fekete, Anne Laure, Gassner, Serge Rudaz, Julie Schappler, et al. (2013) Analytical strategies for the characterization of therapeutic monoclonal antibodies. TrAC Trends in Analytical Chemistry 42: 74-83.

5. Rabah Gahoual, Alain Beck, Emmanuel leLeize Wagner, Yannis Nicolas François (2016) Cutting-edge capillary electrophoresis characterization of monoclonal antibodies and related products. Journal of Chromatography B 1032: 61-78.

6. Goyon A, Excoffier M, Janin Bussat, MC, Bobaly B, Fekete S, et al. (2017) Determination of isoelectric points and relative charge variants of 23 therapeutic monoclonal antibodies. Journal of Chromatography B 10651066: 119-128.

7. Kinoshita M, Nakatsuji Y, Suzuki S, Hayakawa T, Kakehi K (2013) Quality assurance of monoclonal antibody pharmaceuticals based on their charge variants using microchip isoelectric focusing method. Journal of Chromatography A 1309: 76-83.

8. Patrick JS, Lagu AL (2001) Review applications of capillary electrophoresis to the analysis of biotechnology-derived therapeutic proteins. Electrophoresis 22 (19): 4179-4196.

9. Ramalingam Peraman, Kalva Bhadraya, Yiragamreddy Padmanabha Reddy (2015) Analytical Quality by Design: A Tool for Regulatory Flexibility and Robust Analytics. International Journal of Analytical Chemistry 2015: 9.

10. Righetti PG, Sebastiano R, Citterio A (2013) Capillary electrophoresis and isoelectric focusing in peptide and protein analysis. Proteomics 13 (2): $325-340$

11. Shi Y, Li Z, Qiao Y, Lin J (2012) Development and validation of a rapid capillary zone electrophoresis method for determining charge variants of mAb. Journal of Chromatography B 906: 63-68.

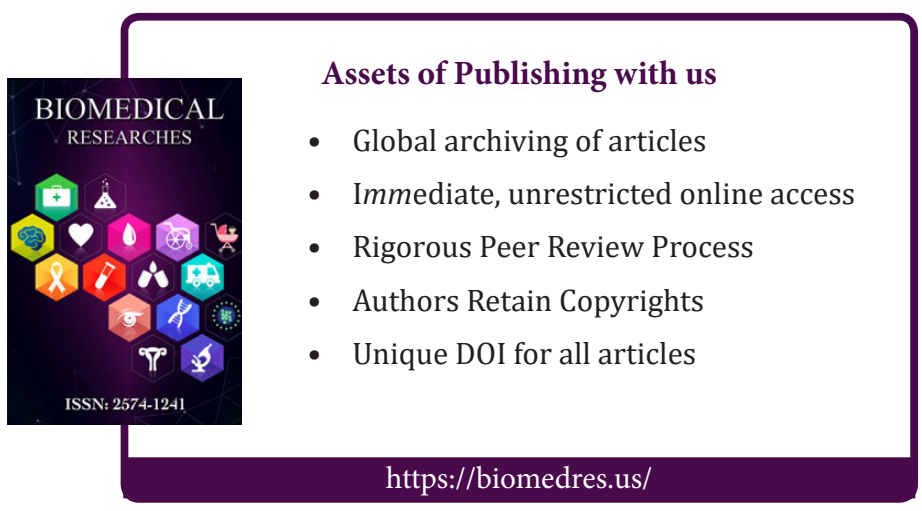

Copyright@ Ju Hyeon Lim | Biomed J Sci \& Tech Res | BJSTR. MS.ID.003782. 